\title{
Keragaan tiga jenis planlet anggrek Phalaenopsis asal Protocorm yang diinduksi Ethyl Methyl Sulfonate (EMS) secara in vitro
}

\section{Performance of three types of Phalaenopsis orchids planlets induced by Ethyl Methylsulfonate (EMS) in vitro}

Diterima : 13 Februari 2018/Disetujui : 13 Maret 2018 / Dipublikasikan : 31 Maret 2018

CDepartment of Crop Science, Padjadjaran University

\begin{abstract}
This research was conducted to determine the effect of concentration of Ethyl Methyl Sulfonate (EMS) to performance of three types of Phalaenopsis Planlets and to know the optimum concentration of EMS on any type of Phalaenopsis orchids. The experiment was conducted at Tissue Culture Laboratory of the Faculty of Agriculture, Winaya Mukti University, Sumedang. It used a completely randomized design (CRD) with factorial pattern, that consisted of two factors and replicated twice.The first factor was the type of Phalaenopsis that resulted form hybridization which consisted of $\mathrm{v}_{1}$ (Phalaenopsis $717 \times$ Phalaenopsis Fire Bird), $v_{2}$ (Phalaenopsis Tianong Rose $\mathrm{X}$ Sibling), and v3 (Phalaenopsis Luchia Pink X Phalaenopsis Chain Xen Mammon). The second factor was the concentration of EMS that consisted of $\mathrm{e}_{0}$ (0\% EMS/control), e 1 (0,05\% EMS), e (0,10\% EMS), e $3(0,15 \%$ EMS $), e_{4}(0,20 \%$ EMS), and e5 $(0,25 \%$ EMS). Explant protocorm of three types of Phalaenopsis soaked in a solution of EMS by each treatment for 3 hours, and cultured on MS medium Basal Modified Multiplication Shoot for 10 weeks. The experimental results showed that there are interaction between the three types of Phalaenopsis result of a cross with a concentration of EMS to variable number of roots. Orchids P. $717 \mathrm{X}$ $P$. Fire Bird had higher number of leaves, number of roots, leaf leang, and root length than the other. The result showed that there were interaction between three species of Phalaenopsis orchid from the crossing with EMS concentration on root variables. Orchid P. 717 X P. Fire Bird has the number of leaves, the number of roots, the number of shoots, leaf length and root length better than other types. EMS concentrations independently at

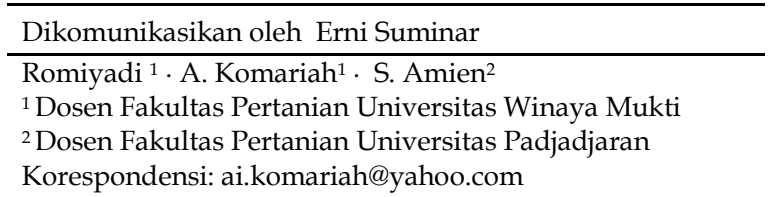

all levels of treatment can not increase the number of leaves, the number of roots, fresh weight of planlet, leaf length, and root length.

Keywords: Phalaenopsis, the concentration of EMS, in vitro culture

Sari. Penelitian ini mempelajari dan mengetahui pengaruh konsentrasi Ethyl Methyl Sulfonate (EMS) terhadap keragaan planlet tiga jenis anggrek Phalaenopsis asal protocorm dan mencari konsentrasi optimum EMS untuk setiap jenis anggrek Phalaenopsis secara in vitro.Percobaan dilaksanakan di Laboratorium Kultur Jaringan Fakultas Pertanian Universitas Winaya Mukti Sumedang. Eksperimen menggunakan Rancangan Acak Lengkap (RAL) Pola Faktorial, yang terdiri atas dua faktor dan diulang sebanyak dua kali.Faktor pertama adalah jenis anggrek Phalaenopsis hasil persilangan yang terdiri atas tiga jenis, yaitu $\mathrm{v}_{1}$ (Phalaenopsis $717 \mathrm{X}$ Phalaenopsis Fire Bird), V2 (Phalaenopsis Tianong Rose X Sibling), dan v3 (Phalaenopsis Luchia Pink X Phalaenopsis Chain Xen Mammon). Faktor kedua adalah EMS yang terdiri atas enam taraf perlakuan, yaitu e 0 (0\% EMS/kontrol), e 1 (0,05\% EMS), e 2 (0,10\% EMS), e 3 (0,15\% EMS), e 4 (0,20\% EMS), dan es $(0,25 \%$ EMS). Eksplan berupa protocorm dari tiga jenis anggrek Phalaenopsis hasil persilangan yang direndam dalam larutan EMS berdasarkan masing-masing perlakuan selama 3 jam, dan dikulturkan pada media MS Modified Multiplication Shoot Basal selama 10 minggu.Hasil penelitian menunjukkan terjadi interaksi antara tiga jenis anggrek Phalaenopsis hasil persilangan dengan konsentrasi EMS terhadap variabel jumlah akar.Anggrek P. 717 X P.Fire Bird memiliki jumlah daun, jumlah akar, jumlah tunas, panjang daun dan panjang akar yang lebih baik dibandingkan jenis lainnya. Konsentrasi EMS secara mandiri pada semua taraf perlakuan tidak dapat meningkatkan jumlah daun, jumlah akar, bobot 
segar planlet, panjang daun, dan panjang akar.

Kata Kunci: Phalaenopsis, Konsentrasi EMS, dan Budidaya In Vitro

\section{Pendahuluan}

Phalaenopsis yang biasa disebut dengan "anggrek bulan" merupakan salah satu anggrek epifit yang paling banyak digemari oleh masyarakat, baik dari jenis spesies maupun hibrida.Saat ini pamor Phalaenopsis telah mendunia, merambah seluruh Asia, Eropa, bahkan Amerika. Phalaenopsis menduduki peringkat paling atas dalam perdagangan tanaman hias anggrek di Indonesia (Virnanto, 2010) dalam Qosim, Istifadah, Djatnika, dkk 2012)), Phalaenopsis dinobatkan sebagai bunga nasional, yaitu Puspa Pesona (Direktorat Tanaman Hias (2004) dalam Qosim $d k k$ (2012)).

Melalui studi kasus di lapangan, salah satu upaya yang dilakukan oleh penyilang anggrek di dalam negeri (termasuk penulis) untuk membuat jenis-jenis baru dari anggrek Phalaenopsis adalah dengan cara merakit hibrida baru melalui persilangan. Namun hal ini belum tentu memuaskan karena: (1) Hibrida yang dihasilkan belum tentu memiliki karakteristik yang diinginkan dan unik, (2) dari sekian banyak hasil persilangan kemungkinan hanya satu sampai 10 individu yang terseleksi memenuhi standar yang diinginkan, dan (3) setelah mendapatkan satu sampai 10 individu yang terseleksi, para penyilang belum mampu memperbanyak individu tersebut secara masal atau secara mericlone untuk menghasilkan individu yang seragam dalam jumlah sangat banyak. Upaya lain yang dapat dilakukan untuk memperluas variasi dari hasil persilangan tersebut adalah dengan cara memberi perlakuan bahan mutagen kimia pada bahan eksplan protocorm seperti Ethyl Methylsulfonate (EMS). Menurut Flick (1983) dalam Soertini Soedjono (2003), menyatakan bahwa aplikasi mutasi induksi dengan mutagen kimia EMS secara in vitro menghasilkan keragaman fenotipik yang lebih luas, yaitu paling sedikit terdapat 25 karakter yang berbeda.

Berdasarkan sel yang bermutasi, mutasi dibagi menjadi dua macam yaitu mutasi somatik dan mutasi gametik.Mutasi somatik adalah mutasi yang terjadi pada sel somatik, yaitu sel tubuh seperti sel kulit.Mutasi ini tidak akan diwariskan pada keturunannya.Mutasi yang disebabkan oleh mutagen kimia seperti EMS termasuk kedalam mutasi gametik karena dapat mengubah informasi genetik pada suatu individu seperti transisi, tranversi, dan delesi basa (Crowder, 1986), sehingga bersifat diwariskan pada turunannya. Pada jaringan sel yang muda dan aktif membelah seperti protocorm dampak dari mutagen dapat direspon lebih peka sehingga pendeteksian terhadap kemungkinan terjadinya mutasi dapat dideteksi sejak dini dengan pendekatan nilai persentase kematian $50 \%$ protocorm yang diinduksi mutagen atau Lethal Concentration 50\% $\left(\mathrm{LC}_{50}\right)$. Selain itu terjadinya perubahan fisik seperti warna protocorm atau jumlah klorofil yang terkandung di dalamnya dapat dijadikan indikasi terjadinya mutasi. Hasil penelitian Qosim $d k k$ (2012), LC 50 pada tunas anggrek bulan hibrida yang diinduksi mutagen kimia EMS secara in vitro terdapat pada konsentrasi $0,025 \%$ dan $0,05 \%$ karena memberikan pengaruh terbaik terhadap pembentukan tunas. Pada konsentrasi diatas 0,15\% tidak disarankan untuk diaplikasikan karena menyebabkan kematian pada eksplan.

Penelitian ini bertujuan untuk mempelajari dan mengetahui pengaruh konsentrasi EMS terhadap keragaan planlet tiga jenis anggrek Phalaenopsis hasil persilangan asal protocorm dalam budidaya in vitro, serta memperoleh konsentrasi optimum EMS pada setiap jenis anggrek Phalaenopsis hasil persilangan untuk mencapai pertumbuhan tertinggi.

\section{Bahan dan Metode}

Eksperimen dilaksanakan di Laboratorium Bioteknologi Tanaman Fakultas Pertanian Universitas Winaya Mukti.Bahan-bahan yang digunakan dalam penelitian ini meliputi protocorm tiga jenis anggrek Phalaenopsis hasil persilangan (Phalaenopsis 717 X Phalaenopsis Fire Bird, Phalaenopsis Tianong Rose X Sibling, dan Phalaenopsis Luchia Pink X Phalaenopsis Chain Xen Mammon) hasil kultur biji, media budidaya in vitro Murashige Modified Shoot Multiplication Basal Medium (mengandung FeNa-EDTA, Sodium Phosphate, Adenine Hemisulfate, 30 mg.L-1 2iP dan 0,3 mg.L-1 IAA), 30 g.L. $\mathrm{L}^{-1}$ sukrosa, 6 g.L-1 gerlite (Gellan Gum), 0,5 ml.L-1 PPM, 2 g.L1 arang aktif, clorox (pemutih pakaian), kapas, karet gelang, plastik kantong bening, label, aquades steril, tisu steril, alumunium foil, alkohol 70\%, dan formalin powder. Alat-alat 
yang digunakan meliputi timbangan digital, botol-botol kultur, tutup botol karet, enkas (ruang tranfer), pinset panjang dan pinset kecil, autoclave, kompor gas, panci dan sendok sayur, corong, lap, beaker glass, gelas ukur, pipet ukur dan bola karet, alat tulis, rak kultur (dilengkapi lampu TL), termometer, dan Air Conditioner (AC).

Penelitian menggunakan Rancangan Acak Lengkap (RAL) Pola Faktorial.Faktor pertama adalah jenis anggrek Phalaenopsis hasil persilangan yang terdiri dari tiga jenis yaitu Phalaenopsis $717 \times$ Phalaenopsis Fire Bird, Phalaenopsis Tianong Rose X Sibling, Phalaenopsis Luchia Pink X Phalaenopsis Chain Xen Mammon. dan faktor kedua adalah konsentrasi EMS yang terdiri dari enam taraf yaitu $\mathrm{e}_{0}=$ Kontrol $(0 \%)$, $\mathrm{e}_{1}$ $=0,05 \%, \mathrm{e}_{2}=0,10 \%, \mathrm{e}_{3}=0,15 \%, \mathrm{e}_{4}=0,20 \%, \mathrm{e}_{5}=$ $0,25 \%$, masing-masing perlakuan yang diulang sebanyak dua kali. Respons yang diamati sebagai penunjang adalah temperatur ruangan laboratorium, kontaminasi bakteri dan cendawan, penampilan dan warna planlet. Respons utama meliputi jumlah daun, jumlah akar, jumlah tunas, bobot segar protocorm 10 minggu setelah tanam $(\mathrm{g})$, panjang daun $(\mathrm{mm})$, panjang akar (mm), persentase kematian planlet $(\%)$.

Pelaksanaan penelitian meliputi persiapan dan sterilisasi alat, persiapan media tanam dengan bahan dasar media Murashige Modified Shoot Multiplication Basal Medium, persiapan larutan EMS untuk merendam protocorm adalah $20 \mathrm{~mL}$ per perlakuan. Proses perendaman protocorm pada larutan EMS dan penanaman eksplan.Eksplan anggrek Phalaenopsis dari ketiga jenis yang digunakan berupa protocorm, diperoleh dari kultur biji yang telah berkecambah, serta diupayakan memiliki ukuran dan umur yang sama (dalam penelitian ini menggunakan protocorm yang berumur enam bulan).Penanaman dilakukan pada kotak steril (enkas) kedap udara yang terbuat dari kaca dengan metode pensterilan menggunakan formalin powder selama 24 jam.Pemeliharaan hanya melakukan sanitasi lingkungan terutama dari debu-debu yang menempel pada dinding botol. Kemudian menjaga temperatur agar tidak terlalu tinggi dengan cara mengatur temperatur ruangan dengan AC.

Untuk mengetahui dan menguji pengaruh macam jenis anggrek dan konsentrasi EMS yang ditumbuhkan pada medium Murashige Modified Shoot Multiplication Basal secara in vitro terhadap variabel pengamatan tanaman dianalisis dengan
Uji F pada taraf nyata $5 \%$, sedangkan apabila terjadi keragaman nyata maka dilakukan dengan Uji lanjutan jarak berganda Duncan pada taraf nyata 5\% (Steel, R.G.D dan J.H. Torrie, 1991)

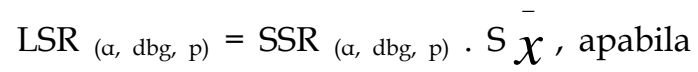

tidak terjadi interakasi maka dilakukan dengan Uji lanjutan untuk mengetahui efek mandiri dari masing-masing perlakuan dengan rumus LSR $(\alpha$, $\mathrm{dbg}, \mathrm{p})=\operatorname{SSR}(\mathrm{a}, \mathrm{dbg}, \mathrm{p})$. S. Untuk mencari konsentrasi optimum EMS pada tiap jenis anggrek Phalaenopsis hasil persilangan digunakan teknik kurva respon dengan model penduga/persamaan regresi kuadratik \% (Steel, R.G.D dan J.H. Torrie, 1991)

seperti berikut $\hat{Y}=b_{0}+b_{1} X+b_{2} X^{2}$

\section{Hasil dan Pembahasan}

Temperatur Ruangan Laboratorium. Temperatur ruangan laboratorium selama percobaan dipertahankan pada $27{ }^{\circ} \mathrm{C}$ agar pertumbuhan dan perkembangan planlet cepat terangsang akibat temperatur yang lebih hangat dibandingkan keadaan normal, yaitu pada kisaran 23$25{ }^{\circ} \mathrm{C}$. Pengaturan temperatur ruangan laboratorium menggunakan Air Conditioner.

Kontaminasi Bakteri dan Cendawan. Selama penelitian tidak ditemukan tejadinya kontaminasi yang disebabkan oleh bakteri dan cendawan. Hal ini terjadi karena proses penutupan botol yang rapat, yaitu menggunakan tutup botol karet yang disumbat dengan kapas pembalut serta dilapisi dengan plastik wrapping sehingga udara kotor tidak dapat masuk ke dalam botol.Selain itu rak kultur juga dijaga kebersihannya dari debu dan kotoran lainnya.

Penampilan dan Warna Planlet. Berdasarkan hasil pengamatan secara visual terhadap warna planlet yang tumbuh dan berkembang terdapat beberapa warna yang dapat dilihat, diantaranya berwarna kuning, hijau dan cokelat kehitaman akibat browning seperti terlihat pada Gambar 1.

Dari gambar 1 dapat diketahui penampilan dan warna planlet P.717 X P.Fire Bird pada berbagai konsentrasi EMS secara visual berbeda, dimana pada pemberian EMS 0,05\% tampilan planlet lebih baik dibandingkan dengan tampilan pada konsentrasi EMS yang lain bahkan dibandingkan dengan yang tanpa pemberian EMS. Planlet pada konsentrasi 0 \% EMS 


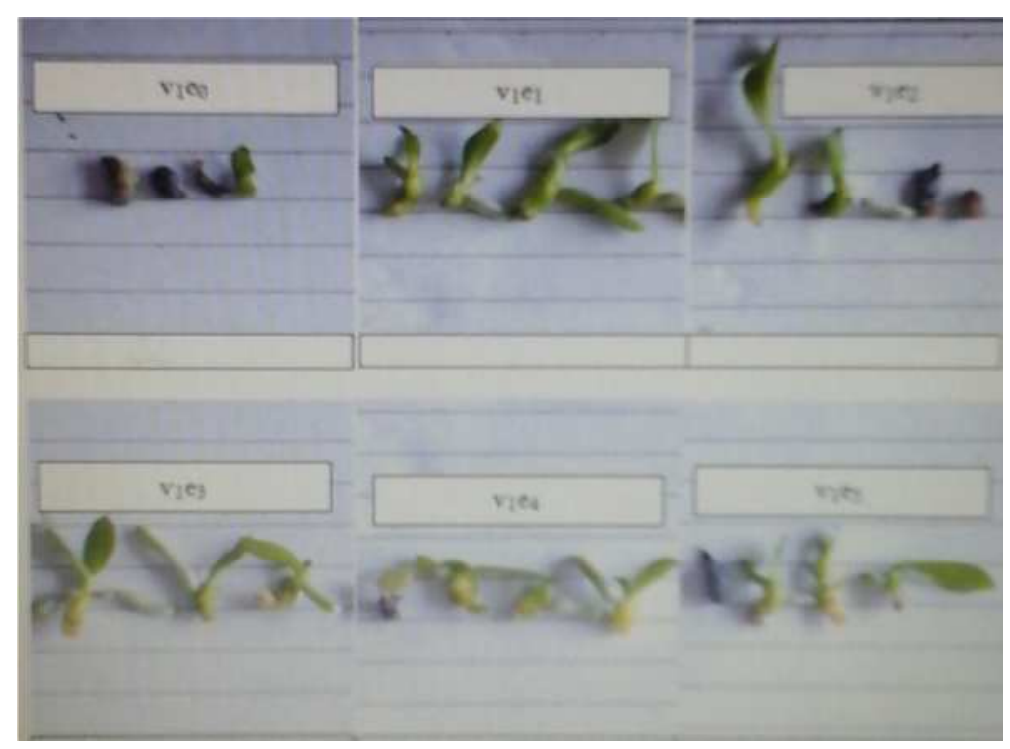

\section{Gambar 1. Keragaan Planlet P.717 X P.Fire Bird pada Konsentrasi EMS $0 \%\left(\mathrm{v}_{1} \mathrm{e}_{0}\right)$, EMS 0,05\% $\left(v_{1} e_{1}\right)$, EMS 0,1\% $\left(v_{1} e_{2}\right)$, EMS 0,15\% $\left(v_{1} e_{3}\right)$, EMS 2\% $\left(v_{1} e_{4}\right)$ dan EMS 0,25\% $\left(v_{1} e_{5}\right)$}

menunjukkan warna yang berbeda yaitu hijau, putih, dan hitam kecokelatan (browning) dan hanya 1 planlet yang tumbuh baik. Warna browning dikarenakan adanya senyawa fenol. Anggrek merupakan salah satu tanaman yang mudah mengeluarkan senyawa fenol, sehingga bisa dengan mudah terjadi browning.Pada kultur jaringan eksplan seringkali berubah menjadi coklat (browning) atau hitam (blackening) sesaat setelah isolasi yang selanjutnya dapat menghambat pertumbuhan dan akhirnya menyebabkan kematian jaringan.

Penampilan warna planlet P.717 X P.Fire Bird pada konsentrasi 0,05 \% EMS terdapat satu jenis warna, yaitu hijau.Penampilan planlet dari empat sampel semuanya menunjukan terjadi pertumbuhan daun dan akar, tetapi tidak terdapat perubahan terhadap warna planlet. Secara visual, planlet tampak tumbuh normal.

Warna planlet P.717 X P.Fire Bird pada konsentrasi 0,10 \% EMS terdapat dua jenis warna, yaitu hijau dan hitam kecokelatan (browning).Dari empat sampel, dua diantaranya planlet yang hidup tampak tumbuh normal dan berwarna hijau, sertatumbuh daun dan akar, dua planlet lagi mengalami kematian akibat browning.

Secara visual, warna planlet P.717 X P.Fire Bird pada konsentrasi 0,15\% EMS terdapat dua jenis warna, yaitu hijau dan kuning.Tiga planlet menunjukan pertumbuhan daun dan akar sedangkan yang satu lagi mengalami kematian akibat browning.

Warna planlet P.717 X P.Fire Bird pada konsentrasi $0,20 \%$ EMS terdapat dua jenis warna, yaitu hijau dan kuning.Penampilan empat planlet menunjukan terjadi pertumbuhan daun dan akar dan dua diantaranya mengalami perubahan warna daun dan batang menjadi kuning.Perubahan warna pada batang dan daun tersebut diduga telah terjadi reaksi akibat perlakuan EMS 0,20\%.Pada tanaman Saintpaulia yang diinduksi EMS 0,20\% telah mengalami kimera (variegata) pada daun (Dia Novita Sari, $d k k$ (2017).

Warna planlet P.717 X P.Fire Bird pada konsentrasi $0,25 \%$ EMS terdapat dua jenis warna, yaitu hijau dan hitam.Tiga planlet menunjukan terjadi pertumbuhan daun dan akar, tetapi tidak terdapat perubahan terhadap warna planlet.Satu planlet mengalami kematian akibat browning.Secara visual, planlet yang hidup tampak tumbuh normal dan berwarna hijau.

Pada gambar 2 dapat dilihat warna planlet P.Tianong Rose $\mathrm{X}$ Sibling pada konsentrasi $0 \%$ EMS terdapat satu jenis warna, yaitu hijau.

Penampilan planlet dari tiga sampel menunjukan pertumbuhan terhadap daun dan akar.Secara visual planlet yang hidup tampak tumbuh normal,daun dan akarnya terlihat tumbuh seimbang,tebal dan kekar.

Warna planlet $P$. Tianong Rose $\mathrm{X}$ Sibling pada konsentrasi 0,05\% EMS terdapat satu jenis warna, yaitu kuning.Penampilan empat planlet menunjukan adanya pertumbuhan calon tunas, daun dan akar meskipun tidak terlalu besar. Semua planlet mengalami perubahan warna daun dan batang menjadi kuning. Perubahan 


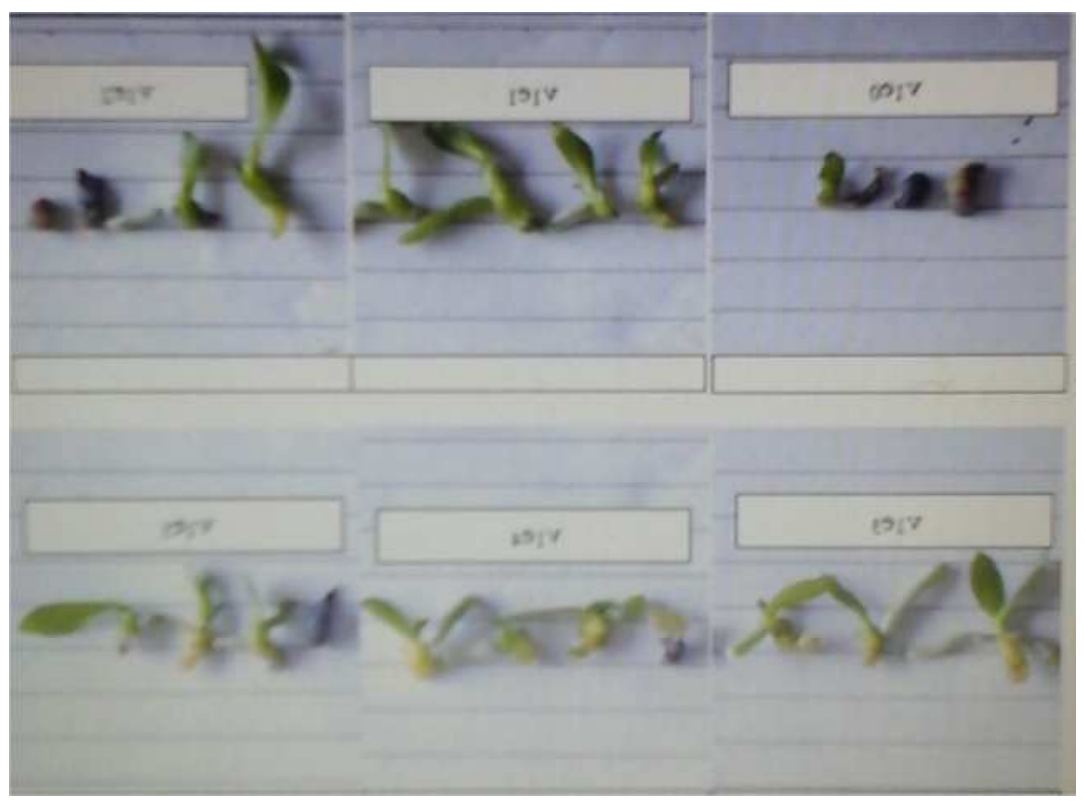

Gambar 2. Keragaan Planlet P. Tianong Rose X Sibling pada Konsentrasi $0 \%$ EMS $\left(\mathrm{v}_{2} \mathrm{e}_{0}\right)$ EMS 0,05\% $\left(v_{2} e_{1}\right)$, EMS 0,1\% $\left(v_{2} e_{2}\right)$, EMS 0,15\% $\left(v_{2} e_{3}\right)$, EMS 0,2\% $\left(v_{2} e_{4}\right)$ dan EMS 0,25\% $\left(v_{2} e_{5}\right)$

warna pada batang dan daun tersebut diduga telah terjadi reaksi akibat perlakuan EMS 0,05\%. Kemunculan daun variegata atau daun dengan campuran warna normal daun yang hijau dengan warna lain, baik putih (albino) ataupun kuning (viridis) menandakan terjadinya proses mutasi klorofil (Sasanti Widiarsih dan Ita Dwimahyani, 2013).

Warna planlet $P$. Tianong Rose $X$ Sibling pada konsentrasi 0,10\% EMS terdapat satu jenis warna, yaitu kuning. Tiga planlet menunjukan pertumbuhan daun dan akar, tetapi tidak terdapat perubahan warna planlet.Satu planlet mengalami kematian akibat browning.Secara visual, planlet yang hidup tampak tumbuh normal.

Warna planlet P.Tianong Rose X Sibling pada konsentrasi 0,15\% EMS terdapat satu jenis warna, yaitu kuning.Penampilan planlet dari empat sampel menunjukan terjadi pertumbuhan terhadap calon tunas, daun dan akar meskipun tidak terlalu besar.Semua planlet mengalami perubahan warna daun dan batang menjadi kuning.Perubahan warna pada batang dan daun tersebut diduga telah terjadi reaksi akibat perlakuan EMS 0,15\%. Terdapat perubahan bentuk dari protocorm menjadi calon tunas pada salah satu sampel planlet, ditunjukkan dengan bentuk planlet yang tidak beraturan.

Warna planlet P.Tianong Rose $\mathrm{X}$ Sibling pada konsentrasi 0,20\% EMS terdapat satu jenis warna, yaitu kuning.Penampilan planlet dari empat sampel menunjukan terjadi pertumbuhan daun meskipun tidak terlalu besar.Satu diantaranya terjadi perubahan warna batang menjadi kuning dan lainnya mengalami browning. Perubahan warna pada batang tersebut diduga telah terjadi reaksi akibat perlakuan EMS 0,20\%.

Warna planlet $P$. Tianong Rose $X$ Sibling pada konsentrasi 0,25\% EMS terdapat satu jenis warna, yaitu kuning dan hitam kecokelatan. Pada semua planlet menunjukan terjadi pertumbuhan terhadap calon tunas meskipun tidak terlalu jelas. Pada dua planlet terjadi perubahan warna batang menjadi kuning dan lainnya mengalami browning serta berwarna putih. Perubahan warna pada batang tersebut diduga telah terjadi reaksi akibat perlakuan 0,25\% EMS. Pengamatan secara visual, pada konsentrasi 0,25\% EMS tampak tidak berpengaruh nyata terhadap terbentuknya daun dan akar, tetapi berpengaruh terhadap terbentuknya calon tunas.Hal ini ditunjukan dengan penampilan ptotocorm yang banyak terdapat gumpalangumpalan kecil seperti calon tunas.

Pada gambar 3 terlihat Warna planlet P.Luchia Pink X P.Chain Xen Mammon pada konsentrasi $0 \%$ EMS terdapat dua jenis warna, yaitu hijau dan hitam kecokelatan.Penampilan planlet $P$. Luchia Pink X P. Chain Xen Mammon menunjukan hampir tidak terjadi pertumbuhan yang nyata. Pertumbuhan daun dari empat sampel hanya terjadi pada satu planlet. Diduga reaksi tersebut dikarenakan faktor genotip 


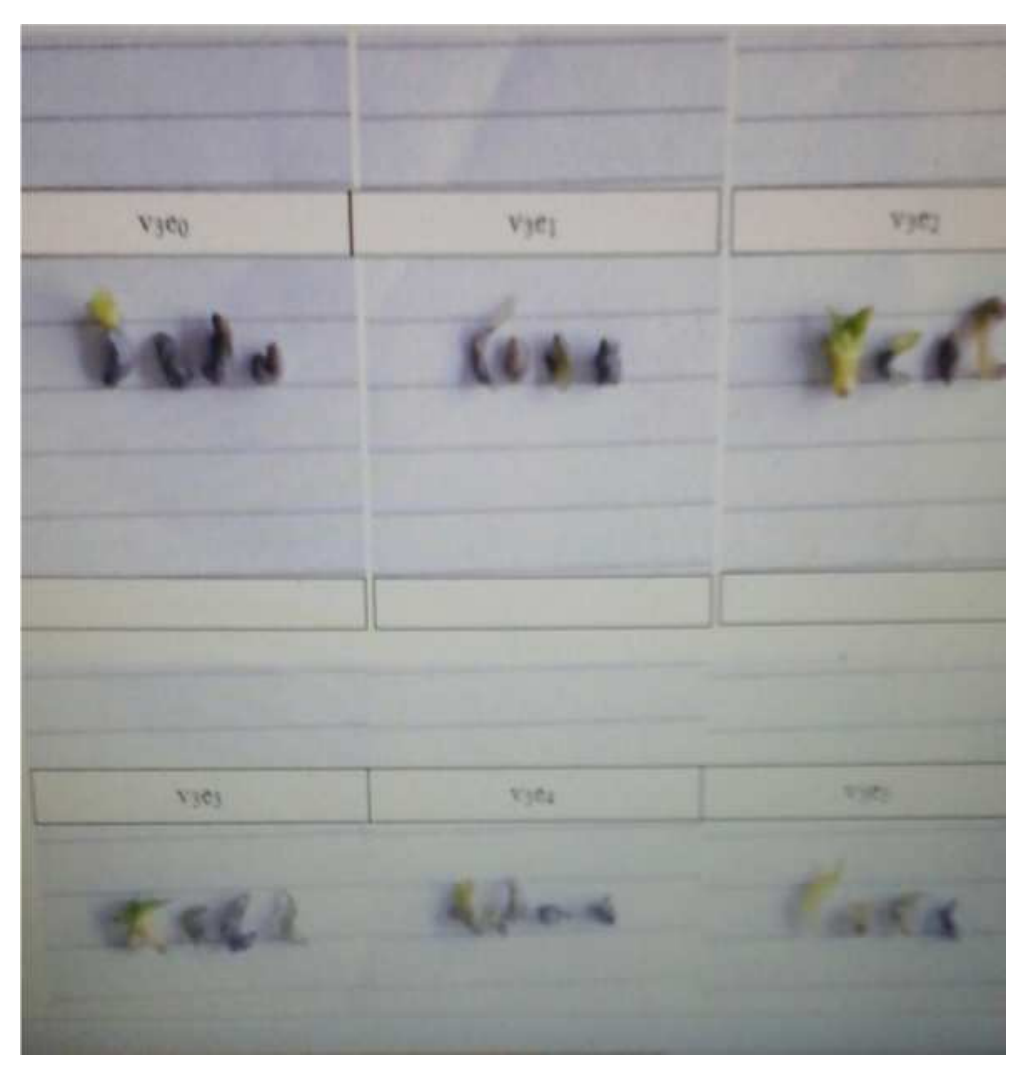

Gambar 3. Keragaan Planlet P.Luchia Pink X P.Chain Xen Mammon pada Konsentrasi 0\% EMS. ( (v $\left._{3} \mathrm{e}_{0}\right)$ EMS 0,05\% ( $\left.v_{3} e_{1}\right)$, EMS 0,1\% $\left(v_{3} e_{2}\right)$, EMS 0,15\% $\left(v_{3} e_{3}\right)$, EMS 0,20\% $\left(v_{3} e_{4}\right)$ dan EMS 0,25\% $\left(v_{3} e_{5}\right)$

tanaman, karena tidak menggunakan perlakuan EMS (0\% EMS). Anggrek merupakan salah satu tanaman yang mudah mengeluarkan senyawa fenol, sehingga tanpa pemberian perlakuan apapun bisa dengan mudah terjadi browning.

Warna planlet P.Luchia Pink X P.Chain Xen Mammon pada konsentrasi 0,05\% EMS terdapat satu jenis warna, yaitu hitam kecokelatan. Penampilan planlet $P$. Luchia Pink X P.Chain Xen Mammon menunjukan hampir tidak terjadi pertumbuhan yang nyata.Semua sampel planlet mengalami browning.

Warna planlet P.Luchia Pink X P. Chain Xen Mammon pada konsentrasi 0,10\% EMS terdapat dua jenis warna, yaitu hijau dan hitam kecokelatan. Penampilan planlet P. Luchia Pink $X P$. Chain Xen Mammon menunjukan adanya pertumbuhan pada salah satu dari empat sampel yang diamati. Dua diantaranya mampu terbentuk daun, tetapi tidak terbentuk akar. Lainnya eksplan tidak mampu tumbuh menjadi planlet karena mengalami browning.

Warna planlet P.Luchia Pink X P. Chain Xen Mammon pada konsentrasi 0,15\% EMS terdapat dua jenis warna, yaitu hijau dan hitam kecokelatan. Penampilan planlet P.Luchia Pink X $P$. Chain Xen Mammon menunjukan adanya pertumbuhan pada satu dari empat sampel yang diamati, yaitu tumbuhnya akar dan daun.Tiga lainnya tisampel lainnya tidak mampu tumbuh karena mengalami browning.

Warna planlet $P$.Luchia Pink X P. Chain Xen Mammon pada konsentrasi 0,20\% EMS terdapat dua jenis warna, yaitu hijau kehitaman dan hitam kecokelatan.Penampilan planlet P.Luchia Pink X P. Chain Xen Mammon menunjukan tidak adanya pertumbuhan yang nyata.Tiga sampel tidak mampu tumbuh menjadi planlet karena mengalami browning. Sedangkan satu planlet hampir mengalami kematian dengan ditunjukkan berubah warna menjadi hijau kehitaman.

Warna planlet P.Luchia Pink X P. Chain Xen Mammon pada konsentrasi 0,25\% EMS terdapat dua jenis warna, yaitu kuning kehitaman dan hitam kecokelatan. Penampilan planlet $P$. Luchia Pink X P. Chain Xen Mammon menunjukan tidak adanya pertumbuhan yang nyata. Tiga sampel tidak mampu tumbuh menjadi planlet karena mengalami browning. Sedangkan satu planlet menunjukan perubahan warna menjadi kuning.

Hasil pengamatan terhadap penampakan planlet terhadap warna dari keseluruhan 
perlakuan adalah bahwa $P$. Tianong Rose $\mathrm{X}$ Sibling menunjukan perubahan warna yang nyata dibandingkan $P .717$ X $P$. Fire Bird dan $P$. Luchia Pink X P. Chain Xen Mammon. Sebagian besar $P$. Tianong Rose $X$ Sibling warna planlet yang dihasilkan berwarna kuning.Sedangkan untuk P. $717 \times$ X . Fire Bird sebagian besar berwarna hijau dan $P$. Luchia Pink $X P$. Chain Xen Mammon lebih cenderung browning.

Menurut Yuyu Suryasari Poerba, jumlah tanaman yang mengalami defisiensi klorofil berupa spot, streaks, kimera pada daun cenderung meningkat dosis mutagen EMS hingga dosis 1,5\%. Perlakuan EMS menghasilkan mutasi warna daun bercak-bercak putih pada lembaran daun, atau kimera terlihat hampir pada semua perlakuan EMS.Pada kimera, tanaman terdiri atas jaringan yang berbeda genetisnya, mutasi terjadi hanya pada bagian atau lapisan jaringan daun atau pada seluruh lapisan jaringan. Induksi defisiensi klorofil berkaitan erat dengan aberasi kromosom yang terjadi pada sel-sel tanaman dari biji yang diberi perlakuan mutagen.Pada daun dari biji yang diberi perlakuan EMS, mutasi klorofil ini sering terjadi, bahkan dapat dijadikan salah satu indikator terjadinya mutasi.

Jumlah Daun. Pengaruh interaksi antara jenis anggrek Phalaenopsis dengan konsentrasi EMS terhadap variabel jumlah daun teruji tidak nyata, namun secara mandiri pengaruh tiga jenis anggrek Phalaenopsis keragamannya teruji nyata. Hasil uji beda rata-rata terdapat pada Tabel 1.

Tabel 1 Pengaruh Jenis Anggrek Phalaenopsis dan Konsentrasi EMS terhadap Jumlah Daun Secara In Vitro pada 10 Minggu Setelah Tanam (MST).

\begin{tabular}{lc}
\hline \multicolumn{1}{c}{ Perlakuan } & $\begin{array}{c}\text { Jumlah Daun } \\
\text { (Helai) }\end{array}$ \\
\hline Jenis Anggrek Phalaenopsis (v): & \\
v $_{1}(P .717$ X P. Fire Bird) & $2,28 \mathrm{c}$ \\
v $(P$. Tianong Rose X Sibling) & $2,15 \mathrm{~b}$ \\
v (P. Luchia Pink X P. Chain & $1,60 \mathrm{a}$ \\
Xen Mammon) & \\
\hline EMS (e): & \\
$\mathrm{e}_{0}(0 \%)$ & $1,91 \mathrm{a}$ \\
$\mathrm{e}_{1}(0,05 \%)$ & $2,17 \mathrm{a}$ \\
$\mathrm{e}_{2}(0,10 \%)$ & $2,08 \mathrm{a}$ \\
$\mathrm{e}_{3}(0,15 \%)$ & $1,98 \mathrm{a}$ \\
$\mathrm{e}_{4}(0,20 \%)$ & $1,91 \mathrm{a}$ \\
$\mathrm{e}_{5}(0,25 \%)$ & $1,99 \mathrm{a}$ \\
\hline $\mathrm{K}^{2}$ &
\end{tabular}

Keterangan: Angka rata-rata pada tiap kolom yang diikuti huruf sama menunjukan tidak berbeda nyata menurut Uji Jarak Berganda Duncan pada taraf nyata $5 \%$.
Berdasarkan Tabel 1. terlihat bahwa jumlah daun atara varietas Phalaenopsis $717 \quad \mathrm{X}$ Phalaenopsis Fire Bird, $P$. Tianong Rose $\mathrm{x}$ Sibling dan $P$. Luchia Pink $x P$. Chain Xen Mammon berbeda, dimana $P .717 \times$ X . Fire Bird memiliki jumlah daun paling banyak yaitu sebanyak 2,28 helai.Eksplan protocormyang diinduksi larutan EMS dengan konsentrasi yang berbeda memberikan pengaruh berbeda tidak nyata terhadap peningkatan jumlah daun. Diduga hal ini berkaitan dengan lama waktu pengamatan yang kurang panjang. Pada penelitian tanaman pisang Raja Sereh oleh Yulmira Yanti (2010), perlakuan dengan mutagen EMS secara in vitro menimbulkan waktu yang bervariasi pada munculnya daun pertama pada setiap planlet.

Wahyu Handayati (2013), menyatakan bahwa Peneliti lain melaporkan bahwa induksi mutasi pada tanaman krisan potong melalui perendaman dalam EMS 0,77\% menghasilkan lebih banyak variasi dibandingkan induksi melalui radiasi sinar gamma. Beberapa varian hasil induksi mutasi melalui perendaman dalam EMS 0,77\% mengalami perubahan morfologi daun, yaitu berbentuk hati dan variegata (kimera), memiliki bunga pita berbentuk tunggal dengan variasi jarum, dan berbentuk tunggal dengan variasi dayung.

Jumlah Akar. Pengaruh interaksi antara jenis anggrek Phalaenopsis dengan konsentrasi EMS terhadap variabel jumlah akar teruji nyata. Hasil uji beda rata-rata tersaji pada Tabel 2.

Tabel 2. menunjukkan bahwa pada varietas P. 717 X P. Fire Bird, perendaman eksplan pada larutan EMS berpengaruh terhadap jumlah akar, dimana pada perlakuan EMS 0,05 dan 0,15 jumlah akar lebih banyak dibandingkan dengan perlakuan lainnya.Hal ini menunjukkan bahwa dengan perlakuan perendaman eksplan pada larutan EMS 0,05\% dapat meningkatkan jumlah akar planlet anggrek, tetapi bila konsentrasinya terus ditingkatkan menyebabkan penurunan jumlah akar.Hasil penelitian A. Sri Devi dan L. Mullainathan (2011) terhadap tanaman cabai, disimpulkan bahwa EMS pada dosis tinggi dapat menyebabkan pertumbuhan morfologi tanaman menjadi terhambat. Berbeda dengan hasil penelitian pada tanaman garut yang dilaksanakan oleh Nurmayulis, Susiyanti, Kartina AM., dan Mohamad Ana Syabana (2010), pemberian berbagai konsentrasi EMS hanya berpengaruh pada pertumbuhan tinggi tanaman. Pada vvarietas $P$. Tianong Rose X Sibling, perlakuan EMS pada berbagai konsentrasi dapat 
menurunkan jumlah akar.Sedangkan pada varietas $P$. Luchia Pink $X P$. Chain Xen Mammon, semua taraf perlakuan EMS tidak berpengaruh terhadap jumlah akar.

Pada semua taraf perlakuan EMS maupun pada kontrol (tanpa perlakuan), antara varietas yang diteliti menunjukkan respon jumlah akar berbeda.Perbedaan jumlah akar antara varietas dikarenakan respon setiap varietas yang secara genetik berbeda susunannya akan berbeda terhadap kondisi suatu lingkungan seperti kondisi media yang diberi perlakuan EMS.

Berdasarkan hasil analisis regresi diperoleh bentuk hubungan persamaan regresi sebagaimana pada gambar 4. Berdasarkan persamaan regresi tersebut diperoleh konsentrasi EMS optimum dengan menghasilkan jumlah akar maksimal pada setiap jenis anggrek Phalaenopsis seperti terdapat pada Tabel 3.

Menentukan nilai $x$ untuk varietas $P .717 \mathrm{X}$ $P$. Fire Bird adalah sebagai berikut:

Pada persamaan:

$$
\begin{aligned}
& Y=-44,13 x^{2}+11,59 x+1,565, R^{2}=0,687 \\
&-88,26 x+11,59= 0 \\
&-88,26 x=-11,59 \\
& x=\frac{-1,59}{-88,26} \\
& x=0,13
\end{aligned}
$$

Jadi, konsentrasi optimum EMS pada varietas $P$. 717 X P. Fire Bird adalah 0,13\%.

Berdasarkan persamaan regresi maka diketahui konsentrasi optimum EMS pada varietas yang diuji sebagaimana terdapat pada Tabel 3 .

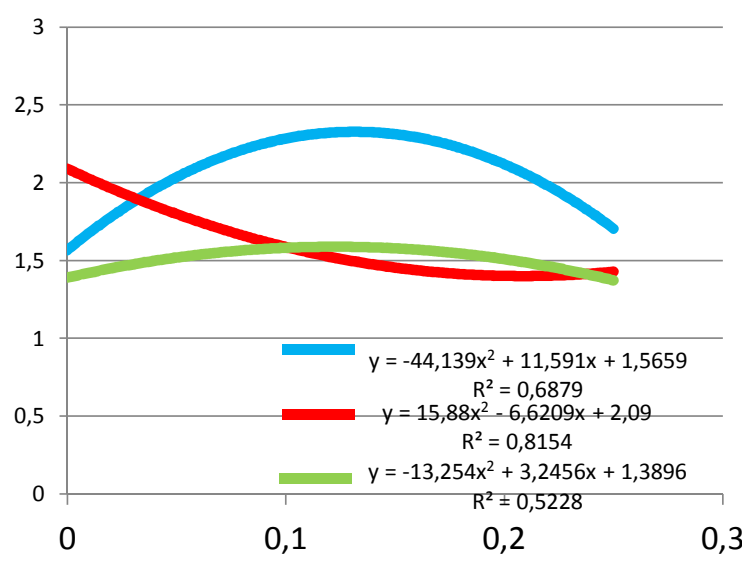

Gambar 4. Garis Hubungan Regresi antara Jennis Anggrek Phalaenopsis dengan Konsentrasi EMS terhadap Variabel Jumlah Akar pada 10 Minggu Setelah Tanam (MST)

Tabel 3. Jumlah Akar Maksimum pada Konsentrasi Optimum Tiga Jenis Anggrek Phalaenopsis pada 10 Minggu Setelah Tanam (MST)

\begin{tabular}{lcc}
\hline \multicolumn{1}{c}{$\begin{array}{c}\text { Jenis Anggrek } \\
\text { Phalaenopsis }\end{array}$} & $\begin{array}{c}\text { Nilai } \\
\text { Optimum } \\
\text { Konsentrasi } \\
\text { EMS (\%) }\end{array}$ & $\begin{array}{c}\text { Jumlah Akar } \\
\text { Maksimum }\end{array}$ \\
\hline $\begin{array}{l}\text { P.717 X P. Fire Bird } \\
\begin{array}{l}\text { P. Tianong Rose X } \\
\text { Sibling }\end{array}\end{array}$ 0,13 & 2,32 \\
$\begin{array}{l}\text { P.Luchia Pink X } \quad P . \\
\text { Chain Xen Mammon }\end{array}$ & 0,12 & 1,40 \\
\hline
\end{tabular}

Tabel 2. Pengaruh Jenis Anggrek Phalaenopsis dan Konsentrasi EMS terhadap Jumlah Akar secara In Vitro pada 10 Minggu Setelah Tanam (MST).

\begin{tabular}{cccc}
\hline & \multicolumn{3}{c}{ Jenis Anggrek Phalaenopsis } \\
\cline { 2 - 4 } Konsentrasi EMS & $\mathrm{v}_{2}$ & $\mathrm{~V}_{3}$ \\
\cline { 2 - 4 } & P. 717 & P. Tianong Rose X Sibling & P. Luchia Pink \\
& X P. Fire Bird & $1,084 \mathrm{~b}$. Chain Xen Mammon \\
\hline $\mathrm{e}_{0}$ & $0,707 \mathrm{a}$ & $\mathrm{B}$ & $0,707 \mathrm{a}$ \\
$($ EMS 0\%) & $\mathrm{A}$ & $0,793 \mathrm{a}$ & $\mathrm{A}$ \\
$\mathrm{e}_{1}$ & $1,197 \mathrm{~b}$ & $\mathrm{AB}$ & $0,707 \mathrm{a}$ \\
$($ EMS 0,05\%) & $\mathrm{C}$ & $0,879 \mathrm{a}$ & $\mathrm{A}$ \\
$\mathrm{e}_{2}$ & $1,029 \mathrm{a}$ & $\mathrm{AB}$ & $0,852 \mathrm{a}$ \\
$($ EMS 0,10\%) & $\mathrm{BC}$ & $0,707 \mathrm{a}$ & $\mathrm{A}$ \\
$\mathrm{e}_{3}$ & $1,170 \mathrm{~b}$ & $\mathrm{~A}$ & $0,793 \mathrm{a}$ \\
$($ EMS 0,15\%) & $\mathrm{BC}$ & $0,707 \mathrm{a}$ & $\mathrm{A}$ \\
$\mathrm{e}_{4}$ & $1,025 \mathrm{~b}$ & $\mathrm{~A}$ & $0,707 \mathrm{a}$ \\
$($ EMS 0,20\%) & $\mathrm{BC}$ & $0,707 \mathrm{a}$ & $\mathrm{A}$ \\
$\mathrm{e}_{5}$ & $0,879 \mathrm{a}$ & $\mathrm{A}$ & $0,707 \mathrm{a}$ \\
$($ EMS 0,25\%) & $\mathrm{AB}$ & $\mathrm{A}$ \\
\hline
\end{tabular}

Keterangan: Angka rata-rata yang diikuti huruf kapital (arah baris) dan huruf kecil (arah kolom) yang sama tidak berbeda nyata menurut Uji Jarak Berganda Duncan pada taraf nyata $5 \%$. 
Dapat disimpulkan bahwa, genotipe anggrek Phalaenopsis yang berbeda memberikan respon yang berbeda pula terhadap variabel pertumbuhan dan perkembangan planlet akibat perlakuan konsentrasi EMS.

Jumlah Tunas. Pengaruh interaksi antara jenis anggrek Phalaenopsis dengan konsentrasi EMS terhadap variabel jumlah tunas teruji tidak nyata, secara mandiri pengaruh tiga jenis anggrek Phalaenopsis dengan konsentrasi EMS keragamannya juga teruji tidak nyata. Hasil uji beda rata-rata data pada Tabel 4 .

Tabel 4. Pengaruh Jenis Anggrek Phalaenopsis dan Konsentrasi EMS terhadap Jumlah Tunas secara In Vitro pada 10 Minggu Setelah Tanam (MST)

\begin{tabular}{lc}
\hline \multicolumn{1}{c}{ Perlakuan } & Jumlah Tunas \\
\hline Jenis Anggrek Phalaenopsis (v): & \\
$\mathrm{v}_{1}(P .717$ X P. Fire Bird) & $3,58 \mathrm{a}$ \\
$\mathrm{v}_{2}(P$. Tianong Rose X Sibling) & $3,37 \mathrm{a}$ \\
v $_{3}(P$. Luchia Pink X P. Chain & $2,56 \mathrm{a}$ \\
Xen Mammon) & \\
\hline EMS (e): & \\
$\mathrm{e}_{0}(0 \%)$ & $3,18 \mathrm{a}$ \\
$\mathrm{e}_{1}(0,05 \%)$ & $3,04 \mathrm{a}$ \\
$\mathrm{e}_{2}(0,10 \%)$ & $3,02 \mathrm{a}$ \\
$\mathrm{e}_{3}(0,15 \%)$ & $3,08 \mathrm{a}$ \\
$\mathrm{e}_{4}(0,20 \%)$ & $3,14 \mathrm{a}$ \\
$\mathrm{e}_{5}(0,25 \%)$ & $3,56 \mathrm{a}$ \\
\hline
\end{tabular}

Keterangan: Angka rata-rata pada tiap kolom yang diikuti huruf sama menunjukan berbeda tidak nyata menurut Uji Jarak Berganda Duncan pada taraf nyata $5 \%$.

Berdasarkan Tabel 4. Diketahui bahwa antara varietas tidak terdapat perbedaan jumlah tunas yang terbentuk, demikian pula EMS dengan konsentrasi berbeda tidak berpengaruh terhadap jumlah tunas yang terbentuk.Hal tersebut diduga respon jumlah tunas belum kelihatan ada perbedaan pada waktu pengamatan, karena pada penelitian pendahuluan baru terlihat perbedaan pada umur 15 bulan.

Hasil penelitian Qosim, $d k k$ (2015), dijelaskan bahwa regenerasi tunas pada eksplan dua genotip asal Purwakarta dan Pandeglang memiliki respons yang berbeda akibat perlakuan mutagen EMS. Pada perlakuan genotip asal Purwakarta pada EMS 0,1\% menghasilkan waktu muncul tunas lebih cepat dan jumlah tunas per eksplan paling tinggi, sedangkan perlakuan genotip asal Pandeglang pada perlakuan EMS 0,15\% memiliki nilai paling tinggi pada karakter tinggi tunas. Perlakuan genotip asal Purwakarta pada EMS 0,2
$\%$ merupakan perlakuan paling baik pada karakter jumlah pasang daun.Hal ini menunjukkan bahwa, pengaruh varietas terhadap respon EMS berbedabeda. Faktor genotip merupakan salah satu penyebab respon tanaman berbeda. Begitu pula pada penelitian ini, faktor varietas (genotip) ternyata berperan penting dalam keefektifian respon terhadap mutagen kimia seperti EMS.

Bobot Segar Planlet (g). Pengaruh interaksi antara jenis anggrek Phalaenopsis dengan konsentrasi EMS terhadap variabel bobot segar planlet teruji tidak nyata, secara mandiri pengaruh tiga jenis anggrek Phalaenopsis dengan konsentrasi EMS keragamannya juga teruji tidak nyata. Hasil uji beda rata-rata data terdapat pada Tabel 5.

Tabel 5. Pengaruh Jenis Anggrek Phalaenopsis dan Konsentrasi EMS terhadap Bobot Segar Planlet secara In Vitro pada 10 Minggu Setelah Tanam (MST)

\begin{tabular}{lc}
\hline \multicolumn{1}{c}{ Perlakuan } & $\begin{array}{c}\text { Bobot Segar Planlet } \\
(\mathrm{g})\end{array}$ \\
\hline Jenis Anggrek Phalaenopsis $(\mathrm{v})$ & \\
v 1 (P. 717 X P. Fire Bird) & $1,461 \mathrm{a}$ \\
v $(P$. Tianong Rose X Sibling) & $1,462 \mathrm{a}$ \\
v ( $P$. Luchia Pink X P. Chain & $1,440 \mathrm{a}$ \\
Xen Mammon) & \\
\hline EMS (e): & \\
$\mathrm{e}_{0}(0 \%)$ & $1,460 \mathrm{a}$ \\
$\mathrm{e}_{1}(0,05 \%)$ & $1,458 \mathrm{a}$ \\
$\mathrm{e}_{2}(0,10 \%)$ & $1,453 \mathrm{a}$ \\
$\mathrm{e}_{3}(0,15 \%)$ & $1,459 \mathrm{a}$ \\
$\mathrm{e}_{4}(0,20 \%)$ & $1,450 \mathrm{a}$ \\
$\mathrm{e}_{5}(0,25 \%)$ & $1,447 \mathrm{a}$ \\
\hline
\end{tabular}

Keterangan: Angka rata-rata pada tiap kolom yang diikuti huruf sama menunjukan berbeda tidak nyata menurut Uji Jarak Berganda Duncan pada taraf nyata 5\%.

Berdasarkan Tabel 5 menunjukan bahwa antara tiga jenis anggrek Phalaenopsis dan konsentrasi EMS pada semua taraf berpengaruh tidak nyata pada peningkatan bobot segar planlet. Diduga pada saat pengamatan responsnya belum terlihat karena pada pada penelitian pendahuluan dengan lama waktu 15 bulan, perlakuan tiga jenis anggrek Phalaenopsis dan konsentrasi EMS memberikan pengaruh yang nyata terhadap bobot segar planlet. Hal ini sejalan dengan penelitian Sari Anugrah Lukmaningtias (2014), yang menyatakan bahwa kedelai Anjasmoro yang diberi perlakuan mutasi memiliki waktu muncul bunga dan polong lebih lambat, tinggi tanaman meningkat, jumlah polong total, isi, berat polong sebelum 
jemur, berat polong setelah jemur, jumlah biji, berat biji pertanaman, serta berat 100 biji mengalami peningkatan hasil.Namun pada parameter kandungan karbohidrat yang berupa kandungan gula reduksi dan sukrosa, kedelai mutasi memiliki kandungan karbohidrat beragam, namun ratarata lebih rendah dibandingkan dengan kedelai kontrol.

Panjang Daun (mm). Pengaruh interaksi antara jenis anggrek Phalaenopsis dengan konsentrasi EMS terhadap variabel panjang daun teruji tidak nyata, namun secara mandiri pengaruh tiga jenis anggrek Phalaenopsis keragamannya teruji nyata.Hasil uji beda ratarata pada Tabel 6 .

Berdasarkan Tabel 6 terlihat bahwa antara varietas P.717 X P. Fire Bird, $P$. Tianong Rose $\mathrm{x}$ Sibling dan $P$. Luchia Pink $\times P$. Chain Xen Mammon menunjukan perbedaan panjang daun, dimana varietas atau jenis $P .717 \times$ P. Fire Bird memiliki daun lebih panjang dibandingkan jenis lainnya, yaitu sebesar 3,745 mm.

Tabel 6. Pengaruh Jenis Anggrek Phalaenopsis dan Konsentrasi EMS terhadap Panjang Daun secara In Vitro pada 10 Minggu Setelah Tanam (MST)

\begin{tabular}{lc}
\hline \multicolumn{1}{c}{ Perlakuan } & Panjang Daun $(\mathrm{mm})$ \\
\hline Jenis Anggrek Phalaenopsis $(\mathrm{v}):$ & \\
$\mathrm{v}_{1}(P .717$ X P. Fire Bird) & $3,745 \mathrm{c}$ \\
$\mathrm{v}_{2}(P$. Tianong Rose X Sibling) & $3,130 \mathrm{~b}$ \\
$\mathrm{v}_{3}(P$. Luchia Pink X P. Chain & $1,765 \mathrm{a}$ \\
Xen Mammon) & \\
\hline EMS (e): & $2,588 \mathrm{a}$ \\
$\mathrm{e}_{0}(0 \%)$ & $3,273 \mathrm{a}$ \\
$\mathrm{e}_{1}(0,05 \%)$ & $3,374 \mathrm{a}$ \\
$\mathrm{e}_{2}(0,10 \%)$ & $2,678 \mathrm{a}$ \\
$\mathrm{e}_{3}(0,15 \%)$ & $2,926 \mathrm{a}$ \\
$\mathrm{e}_{4}(0,20 \%)$ & $2,442 \mathrm{a}$ \\
\hline
\end{tabular}

Keterangan: Angka rata-rata pada tiap kolom yang diikuti huruf sama menunjukan berbeda tidak nyata menurut Uji Jarak Berganda Duncan pada taraf nyata 5\%.

Eksplan protocorm yang diinduksi dalam larutan EMS dengan konsentrasi yang berbeda memberikan pengaruh berbeda tidak nyata terhadap peningkatan panjang daun.Hal ini sama dengan pernyataan Ni Made Dewi Rustini dan Made Pharmawati (2014), bahwa EMS berpengaruh tidak nyata terhadap variabel pengamatan panjang daun dan lebar daun. Berbeda dengan pernyataan Yuyu Suryasari Poerba (2000), perlakuan EMS menyebabkan terhambatnya pertumbuhan tanaman. Gaul
(1977) menyatakan bahwa terhambatnya pertumbuhan tanaman pada generasi $\mathrm{M}_{1}$ merupakan kerusakan fisiologis akibat aksi dari mutagen, semakin tinggi dosis mutagen yang digunakan akan semakin besar pula terhambatnya pertumbuhan tanaman pada generasi $\mathrm{M}_{1}$. Hal ini berarti bahwa tanaman yang tahan secara fisiologis akan mengalami hambatan pertumbuhan yang semakin besar akibat pengaruh dosis mutagen. Hal tersebut mengakibatkan menurunnya tinggi tanaman, ukuran daun, jumlah daun dan berat tanaman.Pada perlakuan lain mutagen EMS pada generasi $\mathrm{M}_{1}$ menunjukan hal yang sama, misalnya pada penurunan tinggi tanaman.

Tabel 7. Pengaruh Jenis Anggrek Phalaenopsis dan Konsentrasi EMS terhadap Panjang Akar secara In Vitro pada 10 Minggu Setelah Tanam (MST).

\begin{tabular}{lc}
\hline \multicolumn{1}{c}{ Perlakuan } & Panjang Akar $(\mathrm{mm})$ \\
\hline Jenis Anggrek Phalaenopsis (v): & \\
$\mathrm{v}_{1}(P .717$ X P. Fire Bird) & $3,000 \mathrm{c}$ \\
$\mathrm{v}_{2}(P$. Tianong Rose X Sibling) & $2,093 \mathrm{~b}$ \\
v $_{3}(P$. Luchia Pink X P. Chain & $1,541 \mathrm{a}$ \\
Xen Mammon) & \\
\hline EMS (e): & \\
$\mathrm{e}_{0}(0 \%)$ & $2,166 \mathrm{a}$ \\
$\mathrm{e}_{1}(0,05 \%)$ & $2,600 \mathrm{a}$ \\
$\mathrm{e}_{2}(0,10 \%)$ & $2,135 \mathrm{a}$ \\
$\mathrm{e}_{3}(0,15 \%)$ & $2,455 \mathrm{a}$ \\
$\mathrm{e}_{4}(0,20 \%)$ & $2,164 \mathrm{a}$ \\
$\mathrm{e}_{5}(0,25 \%)$ & $1,748 \mathrm{a}$ \\
\hline
\end{tabular}

Keterangan: Angka rata-rata pada tiap kolom yang diikuti huruf sama menunjukan berbeda tidak nyata menurut Uji Jarak Berganda Duncan pada taraf nyata 5\%.

Panjang Akar (mm). Pengaruh interaksi antara jenis anggrek Phalaenopsis dengan konsentrasi EMS terhadap variabel panjang akar teruji tidak nyata, namun secara mandiri pengaruh tiga jenis anggrek Phalaenopsis keragamannya teruji nyata.Hasil uji beda rata-rata pada Tabel 7 .

Berdasarkan Tabel 7 terlihat bahwa antara P. 717 X P. Fire Bird,P. Tianong Rose $\times$ Sibling dan $P$. Luchia Pink $\times P$. Chain Xen Mammon menunjukkan perbedaan panjang akar, dimana P. $717 \times$ P. Fire Bird memiliki akar panjang paling tinggi dibandingkan $P$. Tianong Rose $\mathrm{x}$ Sibling dan $P$. Luchia Pink $\times P$. Chain Xen Mammon yaitu sebesar $3,000 \mathrm{~mm}$. Eksplan protocorm yang diinduksi dalam larutan EMS dengan konsentrasi yang berbeda memberikan pengaruh berbeda tidak nyata terhadap peningkatan panjang akar.Hal itu dikarenakan 
respons panjang akar akibat EMS belum bias terdeteksi dalam waktu relatif singkat.Pengaruh mutagen terhadap pertumbuhan tanaman pada generasi awal belum dapat terdeteksi kareana pada generasi awal pengaruh mutagen lebih kepada kerusakan fisiologi.Yuyu Suryasari Poerba (2000), menyatakan bahwa keragaman genetik dan/atau perbaikan kualitas tanaman. Karakter-karakter yang dipengaruhi oleh mutagen EMS antara lain: hasil tanaman, umur panen, kandungan kimia, resistensis terhadap penyakit atau hama, hingga perubahan morfologis yang drastis (tanaman pendek atau kerdil) dengan sedikit pengaruh pleitropik yang tidak dikehendaki ((Fehr et al., 1987)

Persentase Kematian Planlet (\%). Pertumbuhan planlet dapat dilihat berdasarkan kemampuan planlet tersebut untuk bertahan hidup Hasil uji beda rata-rata pada pada Tabel 8 menunjukan bahwa induksi mutasi dengan Ethyl Methil Sulfonat berpengaruh tidak nyata, sedangkan faktor genotip anggrek Phalaenopsis menunjukan pengaruh yang nyata terhadap kematian planlet.

Tabel 8. Pengaruh Jenis Anggrek Phalaenopsis dan Konsentrasi EMS terhadap Persentase Kematian Planlet (\%) secara In Vitro pada 10 Minggu Setelah Tanam (MST)

\begin{tabular}{lc}
\hline \multicolumn{1}{c}{ Perlakuan } & $\begin{array}{c}\text { Persentase Kematian } \\
\text { Planlet }(\%)\end{array}$ \\
\hline Jenis Anggrek Phalaenopsis (v): & \\
v $_{1}(P .717$ X P. Fire Bird) & $45,729 \mathrm{a}$ \\
v $_{2}$ (P. Tianong Rose X Sibling) & $87,380 \mathrm{~b}$ \\
v ( $P$. Luchia Pink X P. Chain & $90,660 \mathrm{c}$ \\
Xen Mammon) &
\end{tabular}

\section{EMS (e):}

$\begin{array}{ll}\mathrm{e}_{0}(0 \%) & 36,377 \mathrm{a} \\ \mathrm{e}_{1}(0,05 \%) & 36,025 \mathrm{a} \\ \mathrm{e}_{2}(0,10 \%) & 39,305 \mathrm{a} \\ \mathrm{e}_{3}(0,15 \%) & 38,756 \mathrm{a} \\ \mathrm{e}_{4}(0,20 \%) & 38,756 \mathrm{a} \\ \mathrm{e}_{5}(0,25 \%) & 34,548 \mathrm{a}\end{array}$

Keterangan: Angka rata-rata pada tiap kolom yang diikuti huruf sama menunjukan berbeda tidak nyata menurut Uji Jarak Berganda Duncan pada taraf nyata 5\%.

Anggrek $P .717 \times P$. Fire Bird menunjukan persentase kematian planlet paling rendah dibanding anggrek $P$. Tianong Rose $\mathrm{x}$ Sibbling dan $P$. Luchia Pink $\times P$. Chain Xen Mammon, yaitu sebesar $45,729 \%$. Hal ini berarti anggrek jenis $P .717$ $x P$. Fire Bird memiliki daya tahan terhadap mutagen EMS lebih kuat dibandingkan dengan kedua jenis anggrek Phalaenopsis lainnya.
Kematian planlet sebagian besar berupa browning (pencokelatan), diduga hal tersebut diakibatkan reaksi planlet akibat perendaman dalam EMS dan media tanam.Tidak ditemukan kematian planlet yang diakibatkan oleh kontaminasi cendawan dan bakteri, hal ini menunjukan proses subkultur berjalan dengan baik. Kematian planlet dalam penelitian ini belum dapat dikategorikan sebagai Lethal Concentration $\left(\mathrm{LC}_{50 \%}\right)$, karena perlakuan EMS sebagai mutagen kimia tidak menunjukan keragaman yang nyata.Diduga pula waktu pengamatan penelitian belum mencukupi waktu yang optimal agar EMS dapat memberikan pengaruh yang nyata terhadap planlet. Hal ini sejalan dengan hasil penelitian $\mathrm{Ni}$ Made Dian Pratiwi, Made Pharmawati dan Ida Ayu Astarini (2013) bahwa konsentrasi EMS berpegaruh terhadap persentase tumbuh, tinggi tanaman, jumlah cabang dandiameter bunga Marigold

\section{Kesimpulan}

Berdasarkan hasil penelitian dapat ditarik kesimpulan sebagai berikut: Terjadi interaksi antara tiga jenis anggrek Phalaenopsis hasil persilangan dengan konsentrasi EMS terhadap variabel jumlah akar. Anggrek P. $717 \times$ P. Fire Bird memiliki jumlah daun, jumlah akar, jumlah tunas, panjang daun dan panjang akar yang lebih baik dibandingkan jenis lainnya. Konsentrasi EMS secara mandiri pada semua taraf perlakuan tidak dapat meningkatkan jumlah daun, jumlah akar, bobot segar planlet, panjang daun, dan panjang akar.

\section{Ucapan Terima Kasih}

Terima kasih kepada Dekan Fakultas Pertanian Universitas Winaya Mukti yang telah memberikan kemudahan dalam penggunaan fasilitas Laboratorium Budidaya In Vitro. Terima kasih pula kepada Komisi Pembimbing dan Penguji yang telah membantu dalam memperbaiki hasil penelitian ini. Tidak lupa kepada orang tua dan keluarga tercinta yang selalu mendukung dengan sepenuh hati.

\section{Daftar Pustaka}

A. Sri Devi dan L. Mullainathan. 2011. Genotoxity Effect of Ethyl Methane- 
sulfonate on Root Tip Cell of Chilli (Capsicum annuum L.).World Journal of Agricultural Sciences. 7 (4): 368-374. IDOSI Publications. 2011. India.

Crowder, L. V. 1986. Genetika Tumbuhan (terjemahan: Lilik Kusdiarti). Gadjah Mada University Press.Yogyakarta.

Dia Novita Sari, Syarifah Iis Aisyah, dan Muhammad Rizal Martua Damanik. Sensitivitas dan Keragaan Tanaman Coleus sp. terhadap Mutasi Induksi Kimia Menggunakan Ethyl Methane Sulfonate (EMS) dengan Cara Aplikasi Rendam dan Tetes. J. Agron. Indonesia, April 2017, 45(1):56-63.

Fehr W.R., G.A. Welke, E>G> Hammond, D.N. Duvick, and S.R. Cianzio. 1992. Inheritance of Reduced Falmitic Acid in Seed oil of Soybean. Crof Science 31 (1) : 88-89..

Gaul H., 1977. Mutagen effects in the First Generation After Seed treatment ; Chimera in Manual On Mutation Breeding (Second Edition) IAEA, Vienna. Pp : 98-102

Ni Made Dewi Rustini dan Made Pharmawati. 2014. Aksi Ethyl Methane Sulphonate terhadap Munculnya Bibit dan Pertumbuhan Cabai Rawit (Capsicum frutescens L.). Jurnal Bioslogos, Feb. 2014. Vol. 4.No. 1.

Ni Made Dian Pratiwi, , Made Pharmawati, dan Ida Ayu Astarini. 2013. Pengaruh Ethyl Methyl Sulphonate (EMS) terhadap Pertumbuhan dan Variasi Tanaman Marigold. Agrotop 3(1) : 23-28.

Nurmayulis, Susiyanti, Kartina AM., dan Mohamad Ana Syabana. 2010. Peningkatan Keragaman Tanaman Garut dengan Pemberian Berbagai Konsentrasi dan Lama Perendaman Ethyl Methan Sulphonate. J. Agrivigor. 10(1): 1 - 9.

Qosim W.A., Istifadah N., Djatnika I., dan
Yunitasari. 2012. Pengaruh Mutagen Etil Metan Sulfonat terhadap Kapasitas Regenerasi Tunas Hibrida Phalaenopsis In Vitro. Jurnal Hortikultura 22(4):360 - 365.

Qosim W.A., Yuwariyah W., Y. Hamdani, J.S. Rachmadi M., dan Perdani, S.M. 2015. Pengaruh Mutagen Etil Metan Sulfonat Terhadap regenerasi Tunas Pda Dua Genotip ManggisAsal Purwakarta dan Pandeglang.J.Hort. 25(1) : 9-14.

Sari Anugrah Lukmaningtias.2014. Pengaruh Mutasi Dengan Ethyl Methane Sulfonate (Ems) Terhadap Pertumbuhan, Hasil Dan Kandungan Karbohidrat Tanaman Kedelai (Glycine Max L. Merrill).

Sasanti Widiarsih dan Ita Dwimahyani.2013. Aplikasi Iradiasi Gamma untuk Pemuliaan Mutasi Anggrek Bulan (Phalaenopsis amabilis Bl.) Umur Genjah. Jurnal Ilmiah Aplikasi Isotop dan Radiasi.Vol. 9 No. 1.Hal. $59-66$.

Steel, R.G.D. dan J.H. Torrie. 1991. Priniples and Procedures of Statistics : A Biometrical Approach; 2nd edition. Mc Graw Hill Book co, New York.

Soertini Soedjono. 2003. Aplikasi Mutasi Induksi dan Variasi Somaklonal dalam Pemuliaan Tanaman.Jurnal Litbang Pertanian 22(2) Balai Penelitian Tanaman Hias (BALITHI).Cianjur.

Yulmira Yanti. 2010. Fenotip Peroksidase Pisang Raja Sereh dengan Ethyl Methyl Sulphonate (EMS) Secara In Vitro. J. Agrivita 32(1) : 29-35.

Yuyu Suryasari Poerba. 2000. Pengaruh Mutagen Ethyl Methane Sulphonate terhadap Pertumbuhan Sonchus arvensis L. pada Generasi $\mathrm{M}_{1}$. Puslitbang - LIPI. http:/ / nurul.blog.uns.ac.id/files/2010/05/ 11.pdtf. 